\title{
KILKA SŁÓW O JUBILACIE
}

\author{
Józef Stanielewicz \\ Wydział Zarządzania i Ekonomiki Usług, Uniwersytet Szczeciński
}

Tak niewiele, zdawać by się mogło, upłynęło czasu od jubileuszu 80-lecia Profesora Franciszka Gronowskiego uroczyście obchodzonego na Jego macierzystym Wydziale Zarządzania i Ekonomiki Usług Uniwersytetu Szczecińskiego w 2007 roku i od wyprowadzki Profesora do Bydgoszczy w 2008 roku, a jednak tak bardzo wiele zmieniło się w tym czasie na tworzonym i kierowanym przez Niego wydziale. Odeszło na zawsze z grona profesorskiego kilku kolegów, wielu innych porozjeżdżało się po świecie - być może nie miał ich kto zatrzymać. Sam wydział, mimo imponującego rozwoju bazy materialnej, a także dorobku naukowego jego pracowników, stawał się duchowo uboższy, gubiąc rodzinną atmosferę i charakteryzującą go "lekkość bytu” (w dobrym tego słowa znaczeniu), wyróżniającą go pozytywnie wśród innych jednostek organizacyjnych uczelni. Jestem przekonany, że zabrakło wśród nas moralnego autorytetu i niekwestionowanego przywódcy, który potrafiłby złagodzić skutki niedobrego dla naszej wspólnoty akademickiej czasu przemian, łamiącego ład ustalony przez długą tradycję uniwersytecką, tworzoną przez tak wybitne jednostki jak Profesor Franciszek Gronowski, wybitny uczony, twórca szczecińskiej szkoły gospodarki morskiej, której jest wierny przez całe swoje życie.

Morze zauroczyło Jubilata bardzo wcześnie. Dla chłopca urodzonego w rodzinie chłopskiej w Fedorowiczówce, niedaleko słynnego Zbaraża, jawiło się ono w wymiarze romantycznej przygody i chęci poznania świata. Miejsce urodzenia znajdowało się niezbyt daleko stron rodzinnych naszego wielkiego rodaka Józefa Korzeniowskiego (Josepha Conrada), niedościgłego w światowej literaturze piewcy morza. Lektura dzieł Conrada nie pozostawała bez wpływu na wybór drogi życiowej Jubilata. Duży wpływ (co Profesor Gronowski podkreśla przy każdej okazji) miało także uczestnictwo w działalności Związku Harcerstwa Polskiego, w którego patriotycznym programie sprawy Bałtyku i Pomorza miały przed wojną wymiar priorytetowy, a pieśń „Morze, nasze morze” (będziem ciebie wiernie strzec...) stała się drugim nieoficjalnym hymnem polskich harcerzy. Początki działalności harcerskiej wiązały się z przeprowadzką rodziny Jubilata do Bydgoszczy. Pobyt na Pomorzu przerwała wojna, podczas której został z rodziną wysiedlony do Tarnobrzegu w Generalnej Guberni, dzieląc tragiczny los tysięcy polskich rodzin represjonowanych przez niemieckiego okupanta. Po zakończeniu wojny, jak szybko to było możliwe, rodzina wróciła do Bydgoszczy, a Franciszek Gronowski ukończył w przyspieszonym tempie Liceum Administracyjno-Handlowe, w nietypowym okresie zdał maturę, by zdążyć zapisać się na pierwszy rok studiów prawno-ekonomicznych na powołanym właśnie do 
życia, Uniwersytecie im. Mikołaja Kopernika w Toruniu. W programie studiów zabrakło elementów morskich, sam zaś Torun tracąc definitywnie status stolicy województwa pomorskiego, oddalił się poniekąd od morza. Jubilat podjął więc męską decyzję wyjazdu do Szczecina łamiąc opór rodziców, zwłaszcza przerażonej matki, która czarno widziała przyszłość syna na „dzikim zachodzie”. Po przybyciu do Szczecina w styczniu 1947 roku zapisał się na „drugi rzut studiów” w Akademii Handlowej, podejmując studia na specjalizacji Transport Morski i Handel Zagraniczny, której Jubilat pozostał wierny przez całe życie. Studia w niepublicznej uczelni, w której za naukę i każdy egzamin trzeba było płacić, skierowały świeżo upieczonego studenta do Bratniej Pomocy, co zapewniło mu na początek specjalizację transportową w zakresie dźwigania koksu do prywatnych mieszkań na wyższych piętrach, a także w ich sprzątaniu. Okazał się na tyle pilnym praktykantem, że wkrótce mógł zatrudnić się jako klark w prywatnej firmie agencyjnej „Agmor”. W ten sposób przyszły specjalista z gospodarki morskiej znalazł się po raz pierwszy na morskim statku.

Mimo nawału pracy („obowiązki studenckie”, praca zawodowa urozmaicona korepetycjami udzielanymi mniej zdolnym studentom) Jubilat dyskontował także swoje zdolności artystyczne (natura obdarzyła Go pięknym głosem), występując jako solista na różnych uroczystych akademiach i jubileuszach. Miał jeszcze czas i siły na udział w pracach społecznych na rzecz miasta, czego potwierdzeniem jest stosowny dokument z pieczątką o „spełnionym czynie studenckim przy usuwaniu gruzów miasta Szczecina”.

Podczas studiów pozostawał pod silnym wpływem wybitnych profesorów, wśród których znajdowało się wiele wybitnych osobistości znanych na niwie nauki a także gospodarczych i politycznych osiągnięć Polski międzywojennej. Należał do nich profesor Bolesław Kasprowicz, przedwojenny dyrektor Rady Interesantów Portu w Gdyni, który stworzył podwaliny pod morską specjalizację szczecińskiej uczelni. Profesor Kasprowicz stanął na czele Katedry Transportu Morskiego, która zaoferowała studentom szeroki wachlarz przedmiotów specjalistycznych w tym: ekonomikę żeglugi morskiej, ekonomikę portów morskich z portowym aparatem usługowym oraz handel zamorski, które cieszyły się wielkim zainteresowaniem wśród młodzieży akademickiej. Symbolem morskiego charakteru uczelni stała się złota kotwica haftowania na czapkach studentów szczecińskiej Akademii Handlowej.

Już na drugim roku studiów Jubilat został zaangażowany jako asystent wolontariusz w Katedrze Transportu Morskiego przez profesora Bolesława Koselnika (przedwojennego naczelnika wydziału Urzędu Morskiego w Gdyni), który kontynuował dzieło profesora Kasprowicza zmuszonego przez władze do opuszczenia Szczecina. Wspomina z rozbawieniem, że mógł odtąd nie tylko realizować swoje ambicje dydaktyczno-naukowe, lecz także zgłębiać tajniki dobrych manier i uczyć się pokory wobec „wyższych rangą” - opiekując się wykwintnymi strojami starszych kolegów z katedry, na które składały się sukienne garnitury, a zimą dodatkowo eleganckie wierzchnie okrycia. Do legendy przeszła lisia pelisa, oddana jego pieczy przez jednego ze starszych kolegów, widocznie przedwojenna, bo mocno liniejąca, której młody adept nauki musiał poświęcać szczególnie dużo troski.

Z chwilą przejścia 1 października 1949 roku na pierwszy w życiu etat - młodszego asystenta, Jubilat mógł się już zająć wyłącznie dydaktyką i nauką. Miało to zbawienne skutki dla polskiej nauki, z której właściciel lisiej pelisy odszedł na zawsze stając się ozdobą krajowych i międzynarodowych estrad. 
Sam Jubilat, ciągle jeszcze studiując, zaczął uczyć innych, często dużo starszych od Siebie. Jednocześnie rozpoczął kwerendę naukową, która zaowocowała wkrótce serią wydawniczą, składającą się ze stukilkudziesięciu publikacji związanych z transportem zapleczowym portów i gospodarką morską. Zapoczątkowała ją wydana 60 lat temu publikacja pod tytułem Drogi wodne i transport rzeczny w Polsce.

Godne uwagi jest to, że cała długoletnia działalność naukowo-dydaktyczna Profesora Gronowskiego w macierzystej uczelni, która kilkakrotnie zmieniała nazwę, związana była z wymienioną katedrą, której pozostawał wierny do końca swojego pobytu w Szczecinie. Trudno byłoby podważyć tezę, że dzieje szczecińskiej szkoły transportowej, w której problematyka morska odgrywała rolę szczególną, wiązały się z omawianą katedrą, gdzie przez kilkadziesiąt lat prowadzono zajęcia z zakresu żeglugi morskiej, gospodarki portowej i transportu zapleczowego portów morskich, zwłaszcza żeglugi śródlądowej.

Młodemu pracownikowi naukowemu uczelnia zaoferowała służbowe mieszkanie przy ulicy - jakżeby mogło być inaczej, biorąc pod uwagę muzyczny aspekt Jego biografii - Mieczysława Karłowicza, gdzie Jubilat przez kilkadziesiąt lat „komponował” swoje dzieła związane z uprawą morza.

Brak pełnych uprawnień akademickich w macierzystej uczelni (przekształconej w $1950 \mathrm{r}$. w Wyższą Szkołę Ekonomiczną) sprawił, że Jubilat musiał kontynuować studia w Warszawskiej Szkole Głównej Planowania i Statystyki (obecna Szkoła Główna Handlowa) w której w 1953 roku uzyskał stopień magistra ekonomii. Dalszy awans naukowy Jubilata, zatrudnionego cały czas w tej samej uczelni (w 1955 r. w WSE została włączona jako Wydział Inżynieryjno-Ekonomiczny Transportu do nowo powstałej Politechniki Szczecińskiej, ten zaś w 1985 r. do Uniwersytetu Szczecińskiego), wyprzedzał akademicki rozwój macierzystej uczelni. W rezultacie kolejne stopnie i tytuły naukowe zdobywał w Wyższej Szkole Ekonomicznej w Sopocie (doktor nauk ekonomicznych w 1962 r.) i na Uniwersytecie Gdańskim (doktor habilitowany nauk ekonomicznych w 1966 r.). W 1973 roku otrzymał tytuł profesora nadzwyczajnego, a 1983 roku profesora zwyczajnego.

Podnosząc kwalifikacja naukowe, Jubilat doskonalił warsztat dydaktyczny i wdrażał nowe metody nauczania. Uczniowie Profesora pamiętają Jego piękne wykłady, cenne nie tylko ze względów merytorycznych, lecz także przepojone duchem humanizmu i nieodmiennie, kiedy mówił o morzu, głębokim patriotyzmem.

Autorytet Profesora i wysoka renoma kierowanej przez niego katedry sprawiły, że w okresie żywiołowego rozwoju polskiej gospodarki morskiej, przypadającej na pierwszą połowę lat 70 . XX wieku, „przypisany” do katedry kierunek studiów - ekonomika transportu morskiego cieszył się rekordową popularnością wśród kandydatów na studia. Aby zostać studentem tego morskiego kierunku, należało pokonać podczas egzaminów wstępnych siedmiu-dziewięciu rywali. W katedrze zatrudniano wówczas kilkunastu nauczycieli akademickich, w tym czterech tzw. samodzielnych (profesorów i docentów).

Franciszek Gronowski pracę dydaktyczną łączył z aktywną działalnością w Związku Nauczycielstwa Polskiego, którego władze uhonorowały Go Złotą Odznaką Związku. Od 1970 roku pełnił różne funkcje w administracji uczelni, poczynając od kierownika Katedry. W latach 1972-1982 był prodziekanem, a następnie dziekanem Wydziału Inżynieryjno-Ekonomicznego Transportu. Wieloletnia kierownik dziekanatu pani Józefa Wójcik w eseju na temat „swoich” 
dziekanów (Dłużej klasztora niż przeora, w: Nasza Alma Mater, Szczecin 1966, s. 83) zamieściła trafną ocenę dziekańskiej działalności Jubilata przypadającej na lata stanu wojennego: „W tych trudnych czasach podjął energiczne próby wyrwania pracowników naukowych ze stanu beznadziei, niepewności jutra i ogólnego marazmu, rygorystycznie aktywizując ich do pracy naukowej”. Wypada nadmienić, że dziekan Franciszek Gronowski wykazywał, w tych niezwykle ciężkich, bo przypadających na okres głębokiego załamania gospodarczego latach, głęboką troskę o egzystencję pracowników Wydziału. W pamięci utkwił mi moment pożegnania ogólnie szanowanego, odchodzącego na emeryturę wieloletniego intendenta Wydziału, pana Kazimierza Jóźwiaka. Po wygłoszonym przez dziekana pożegnaniu, wszyscy uczestnicy uroczystości długo wycierali zaczerwienione oczy.

Dziekańska kadencja została nieoczekiwanie przerwana, o czym dowiadujemy się z cytowanego eseju: „25 czerwca 1982 r. Pan dziekan oświadczył Radzie Wydziału: «nadzwyczajne okoliczności wynikające z trudnej sytuacji uczelni skłoniły mnie do podjęcie się szczególnie trudnego zadania, tj. pełnienia obowiązków rektora PS»” (Dłużej klasztora..., s. 84). Biorąc pod uwagę kontekst stanu wojennego i panujący w uczelni stan niepewności jutra, powyższa decyzja Jubilata wymagała wielkiej odwagi i odpowiedzialności. Dla nas, członków Rady Wydziału Inżynieryjno-Ekonomicznego Transportu ważne było, że odchodzący dziekan zadeklarował aktywny udział w pracach rady i wspomaganie jej inicjatyw związanych z powołaniem Uniwersytetu Szczecińskiego, które zmaterializowały się jesienią 1985 roku. Po ukończeniu kadencji rektora, Jubilat pełnił przez dwa lata (1984-1985) funkcję dyrektora Instytutu Ekonomiki Transportu.

Z inicjatywy nowego dyrektora, a także profesora Waldemara Grzywacza powołano do życia unikatową w skali kraju specjalność studiów - ekonomikę i organizację łączności, co zadecydowało, już w czasach uniwersyteckich, o awansie instytutu do rangi samodzielnego Wydziału Transportu i Łączności. Sam Profesor Gronowski należał do nielicznych pracowników przeciwnych wychodzeniu instytutu z Wydziału Ekonomicznego (utworzonego w 1985 r. w miejsce Wydziału Inżynieryjno-Ekonomicznego Transportu), uważając, że w Uniwersytecie winien funkcjonować, wzorem uniwersytetów zachodnich, jeden wielki fakultet ekonomiczny z wieloma kierunkami studiów.

W uniwersytecie, aż do przejścia na emeryturę w 1998 roku, Jubilat kierował Katedrą Transportu Morskiego i Śródlądowego. W zaistniałej trudnej sytuacji kadrowej w katedrze i na wydziale profesor Gronowski, będący już emerytem, zgodził się na dalsze kierowanie katedrą, pod nową nazwą - Katedra Gospodarki Morskiej. Przez pięć lat (1993-1998) pracował dodatkowo na stanowisku profesora w Instytucie Eksploatacji Portów i Floty w Wyższej Szkole Morskiej w Szczecinie.

Franciszek Gronowski harmonijnie godził obowiązki nauczyciela akademickiego z praktyką gospodarczą, rozpoczętą w latach studenckich współpracą z agencją morską „Agmor”. Przez wszystkie kolejne lata związany był ściśle $z$ wieloma agendami gospodarki morskiej. Kierował zespołem, który przygotował liczne opracowania, ekspertyzy i założenia strategiczne rozwoju transportu morskiego. Przez ponad 25 lat przewodniczył społecznie Radzie Techniczno-Ekonomicznej przy Polskiej Żegludze Morskiej w Szczecinie. Od 1952 roku jest arbitrem Międzynarodowego Sądu Arbitrażowego ds. Żeglugi Morskiej i Śródlądowej w Gdyni.

Droga zawodowa Jubilata wytyczona była przez dwa zasadnicze kierunki: 
- $\quad$ wykształcenie dużej liczny absolwentów o szerokiej świadomości morskiej,

- służba gospodarce morskiej przez ścisłe kontakty z praktyką i podnoszenie dzięki niej swoich kwalifikacji i wiedzy.

Realizacja tych celów zaowocowała narodzinami szczecińskiej szkoły gospodarki morskiej, będącej dziełem życia Profesora.

Profesor wypromował około 1000 magistrów ekonomii, którzy zasilili instytucje i przedsiębiorstwa - od stanowisk dyrektorskich po ministerialne włącznie, 24 doktorów nauk ekonomicznych, sprawował opiekę naukową nad kilkoma habilitantami, z których część została już profesorami. Był recenzentem kilkunastu prac doktorskich i habilitacyjnych przygotowywanych w ośrodkach naukowych Warszawy, Gdańska i Szczecina. Opiniował liczne wnioski awansowe na profesorów tytularnych i uczelnianych.

Wychowankowie Jubilata pracowali i pracują we wszystkich liczących się podmiotach gospodarki morskiej Pomorza Zachodniego, a także w innych ośrodkach w kraju i za granicą, zajmując z reguły kierownicze stanowiska. Z gospodarką morską związany jest dorobek naukowy Profesora obejmujący około 200 monografii, artykułów i rozpraw naukowych, a także liczne raporty i prace naukowo-badawcze na rzecz praktyki gospodarczej. Jest niestrudzonym popularyzatorem spraw morza w prasie, radiu i telewizji. Był inicjatorem Sejmików Morskich, które odbywały się przez 25 lat w różnych miejscach polskiego Wybrzeża. Głównym organizatorem Sejmików, podejmujących węzłowe problemy polskiej gospodarki morskiej było Stowarzyszenie Civitas Christiana w Szczecinie i istniejący przy nim Ośrodek Myśli Morskiej - unikatowy w skali kraju propagator spraw morza.

Transformacja polskiej gospodarki w latach 90. XX wieku, dokonująca się w warunkach postępującego regresu ekonomicznego, którego skutki odczuła najboleśniej gospodarka morska, nie stwarzały zachęcającego klimatu do rozwijania badań dotyczących transportu morskiego i gospodarki portowej, a także transportu zapleczowego portów. Z wielkiej Katedry Gospodarki Morskiej Profesora Gronowskiego pozostało zaledwie kilka osób, którzy zatrudnili się w Katedrze Gospodarki Światowej i Transportu Morskiego.

W ostatnich latach swojej działalności naukowej na Wydziale, Profesor Gronowski poświęcił się bez reszty ratowaniu polskiej gospodarki morskiej, której odbudowa winna być, Jego zdaniem, jednym z fundamentów polskiej racji stanu. W swoich publikacjach i licznych oficjalnych wystąpieniach Profesor nie szczędził gorzkich słów pod adresem władz, które odeszły od uprawiania polityki morskiej.

Piszący te słowa zachowa w pamięci postać Profesora Franciszka Gronowskiego - dystyngowanego starszego pana wycierającego ukradkiem łzy - kiedy na stateczku żeglugi śródlądowej wraz z uczestnikami konferencji morskiej organizowanej przez szczecińską Akademię Morską mijaliśmy pustawe nabrzeża portu szczecińskiego i ogromne przestrzenie likwidowanej stoczni.

Uznając zasługi Profesora na niwie naukowo-dydaktycznej i dla rozwoju gospodarki morskiej, uhonorowano go wieloma odznaczeniami regionalnymi (m.in. Odznaką Gryfa Pomorskiego), resortowymi (m.in. Zasłużony Pracownik Morza) i centralnymi: Srebrny i Złoty Krzyż Zasługi, Krzyż Kawalerski, Oficerski i Komandorski Orderu Odrodzenia Polski oraz Medalem Edukacji Narodowej i godnością Zasłużony Nauczyciel PRL.

Konkretny wymiar wrażliwości i zaangażowania Profesora w problemy ludzkie i miejsce człowieka we współczesnym świecie znalazł wyraz w Jego aktywnej działalności w Klubie Ro- 
tariańskim. Idea Rotariańska, którą zaszczepił mu jego pierwszy akademicki mistrz - profesor Bolesław Koselnik, przedwojenny członek klubu, dla którego w 1945 roku zabrakło w Polsce miejsca, urzeczywistniła się w Polsce w 1989 roku, kiedy to między innymi z inicjatywy Jubilata zawiązał się klub w Szczecinie, w którym stał się Członkiem Seniorem.

Wysoki autorytet i szacunek wśród studentów i kadry akademickiej zawdzięczał Profesor nie tylko swoim osiągnięciom naukowym i talentowi dydaktycznemu, lecz także wysokiej etyce zawodowej, otwartości i prostolinijności oraz wrażliwości na ludzkie sprawy.

Mimo formalnego przejścia na emeryturę w lutym 1998 roku Profesor nadal aktywnie uczestniczył w pracach Wydziału Zarządzania i Ekonomiki Usług, pracując na trzech czwartych etatu i kierując katedrą.

Profesor często wraca we wspomnieniach do czasów wczesnej młodości, wiążąc je zazwyczaj z działalnością w Związku Harcerstwa Polskiego, gdzie zdobywał kolejne harcerskie stopnie, poczynając od zucha w 1936 roku, do harcerza orlego w drużynie akademickiej przy uniwersytecie im. Mikołaja w Toruniu w 1946 roku. Wartości zawarte w rocie harcerskiego ślubowania, a także nabyte w "harcerskich latach” zasady społecznego działania, o których będzie pamiętał przez następne „dojrzałe” życie, po okres profesorowania, sprawiły, że stał się nie tylko budzącym szacunek nauczycielem akademickim i przełożonym, lecz także, kiedy wymagała tego sytuacja - kolegą i przyjacielem, na którego pomoc zawsze można liczyć. Harcerski fason nigdy nie opuszczał Jubilata. Długo można by mówić o inicjowanych przez Niego pieszych wyprawach, grzybobraniach, a zwłaszcza o ogniskowym śpiewaniu podczas wojaży pracowników wydziału, kiedy stawał się nieodmiennie duszą towarzystwa i znowu, choć na krótko, naszym harcerskim przełożonym.

Po ponad 60 latach pracy w szkolnictwie wyższym Szczecina, w 2008 roku Profesor Gronowski przeprowadził się do Bydgoszczy - miasta, w którym po wojnie zdawał maturę. Tam kontynuował aż do 2016 roku działalność naukowo-dydaktyczną w Wyższej Szkole Gospodarki - niepublicznej uczelni o uznanej renomie. Znalazł ponadto czas na uprawę ukochanego ogródka, długie spacery z Małżonką, a nawet pisanie zjadliwych felietonów na temat polskiej rzeczywistości, zamieszczanych w ogólnopolskich czasopismach.

Siedemdziesięcioletni trud Profesora Franciszka Gronowskiego i rzeszy jego wychowanków związany z budową polskiej gospodarki morskiej zaowocował w ostatnich latach, biorąc pod uwagę tylko szczecińską część Pomorza, szybkim rozwojem obrotów w tutejszych nowoczesnych już portach, zaskakująco dynamiczną ekspansją licznych, niewielkich stoczni, dających Polsce pozycję światowego wicelidera w produkcji luksusowych jachtów i niedużych specjalistycznych jednostek morskich, rozbudową przemysłu okołoportowego i nowymi miejscami pracy, związanymi z szeroko pojętą gospodarką morską, zaś kontynuacją Sejmików Morskich, ukochanego dziecka Profesora Gronowskiego, są Konferencje Morskie wyznaczające kierunki rozwoju polskiej gospodarki morskiej. 